\title{
Helicase-Like Transcription Factor
}

National Cancer Institute

\section{Source}

National Cancer Institute. Helicase-Like Transcription Factor. NCI Thesaurus. Code C18032.

Helicase-like transcription factor (1009 aa, $114 \mathrm{kDa}$ ) is encoded by the human HLTF gene. This protein plays a role in the regulation of both ATP-dependent remodeling of nucleosomes and gene transcription. 